\title{
The Relationship between Pro-Innovation Factors and the Performance of the European Union Member States and their Regions
}

\author{
Ivana Kraftova ${ }^{1}$, Jiri Kraft ${ }^{2}$ \\ ${ }^{1}$ University of Pardubice \\ Studentska 95, 53210 Pardubice, Czech Republic \\ Email.ivana.kraftova@upce.cz \\ ${ }^{2}$ Technical University in Liberec \\ Studentska 2, 46117 Liberec, Czech Republic \\ E-mail.jiri.kraft@tul.cz
}

cross $^{\text {ref }}$ http://dx.doi.org/10.5755/j01.ee.29.4.19703

The strategic priority of the European Union is research, development and innovation, as has been explicitly stated by its representatives since 2000. However, the reality of supporting research and development, innovation and overall economic performance at the threshold of the Fourth Industrial Revolution is different. Europe is significantly losing its global share in wealth creation.

Therefore, the objective of the article is to identify relationships between the economic performance and the pro-innovation factors, which represents intensity of research and development at the level of national economy of the EU Member States. At their regional level, NUTS 2, the economic performance is compared with the pro-innovation factors, which are represented on the one hand as the proportion of employed persons with higher education or persons working in the field of science and technology, and on the other hand as the proportion of persons employed in the high-tech sector.

Research has shown that the contribution of $R \& D$ spending to economic performance is not invariant, that there is probably a certain degree of saturation for which the increase in these expenditures is associated with lower increases in economic performance in the country. The results of the regional analysis can be used to infer the higher importance of persons employed in research and university-educated workers for the country's economic performance compared to the share of those employed in the high-tech sector.

Keywords: Economic Performance; Research and Development Intensity; Human Resources; European Regions; Innovation; Smart Specialisation.

\section{Introduction}

Referring to the link between economic performance and innovation processes linked to $\mathrm{R} \& \mathrm{D}$ is not a novelty; on the contrary, it is a highly accentuated relationship regarded as strategic within the European Union. The Lisbon Strategy for the period 2000-2010 created an unfulfilled vision when it described the EU in 2010 as "the most competitive and dynamic knowledge-based economy in the world capable of sustaining economic growth with more and better jobs and greater social cohesion", (European Communities, 2004). The follow-up report by a team of European experts led by W. Kok sought to realise this idea and highlighted the key moments for sustainable growth by identifying the main paths for improving Europe's performance and competitiveness in the world. Research and development is referred to as an absolute priority, which is justified by the fact that "there is strong evidence that productivity growth is greater the higher the $R \& D$ spending ... research shows that up to $40 \%$ of labour productivity growth is generated by these expenditures ... "(European Communities, 2004: 15). Kok's report mentions the announced target from 2002 of spending at least $3 \%$ of gross domestic product on research by 2010 , two-thirds of which should be funded by the business sector.
Europe's real position in the world is evidence of the evolution of the global gross domestic product structure by the continents presented in Figure 1. It clearly shows that Europe began losing its position after 2008, but the position of stagnant America is also being taken over by Asia, where the major growth engine represents the great Chinese economy. According to the forecast of the global PwC consulting firm, the economic dominance of the EuroAmerican region will ultimately end in 2050 (PricewaterhouseCoopers, 2017).

Europe is even lagging behind on long-term development of gross domestic product. If the GDP index of the world's gross domestic product index was $21.82 \%$ between 1970 and 2015, Asia achieved a rate more than double this figure $-52.26 \%$, while America alone was only $18.55 \%$ and Europe only $13.70 \%$.

The year 2010 did not, therefore, bring the European Union, the most important economic entity in Europe, into the condition predicted by the Lisbon Strategy for the period 2000-2010. Its successor, the Europe 2020 strategy, defines three main objectives, the first of which is labelled "smart growth" and represents "developing an economy based on knowledge and innovation" (European Commission, 2010). It also defines the objective in relation to R\&D funding: "3 $\%$ of the EU GDP should be invested in $R \& D "$; in its Annex 
1: "Achieve the target of investing $3 \%$ of GDP in $R \& D$ in particular by improving the conditions for $R \& D$ investment by the private sector and developing a new indicator to track innovation". At the beginning of the new programming period, in July 2014, German GTAI (Germany Trade \& Invest) published a comprehensive document called Industry 4.0 with the subtitle Smart Manufacturing for the Future, which, on the basis of the definition of the concept itself, identifies Germany as a potential global leader in digital development economics (MacDougall, 2014). The digital economy itself, Industry 4.0, based on the so-called Internet of Things, could be labelled according to Valenta's Innovation Classification (Valenta, 2001) as the ninth (the highest) order of innovation, which represents change based on a new approach to nature.

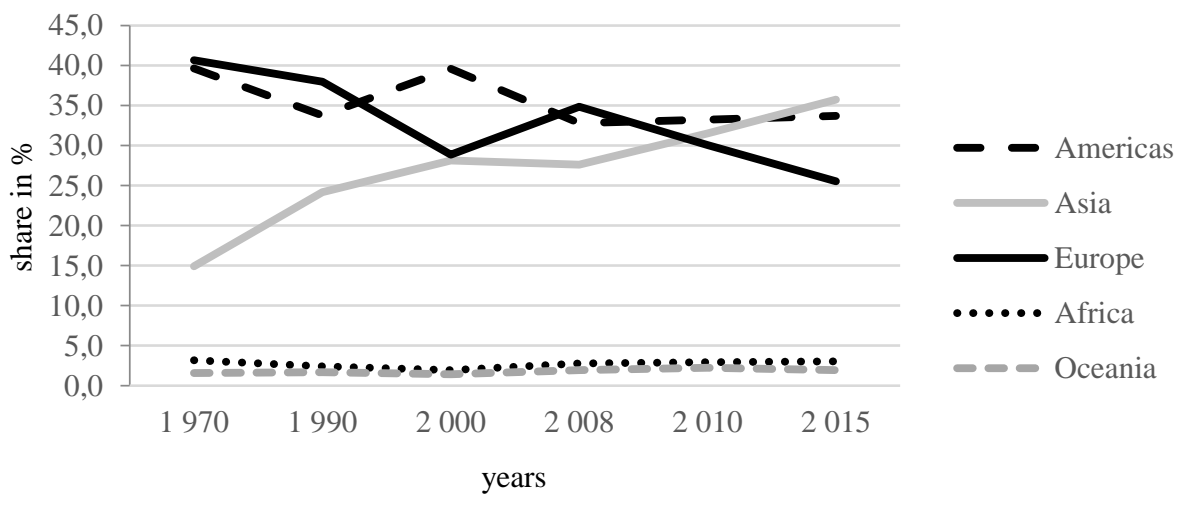

Figure 1. Development in the Global Gross Domestic Product Structure in Selected Years by Continent Source: Customised Processing Using UNSTAT Data (2017)

If innovations are perceived as the conditio sine qua non of economic growth, i.e. of socio-economic development, not only in general, but also within the context of the EU cohesion policy, it is necessary to analyse the relationships between pro-innovation factors and wealth creation, not only in the individual EU Member States but also at their regional level.

In view of the changing circumstances, this analysis must be combined with the period that is characterised as the beginning of the Fourth Industrial Revolution, which anticipates the expectations of significant innovation performance associated with the development of the digital economy, and at the same time represents a new stage in meeting the EU's 2014-2020 objectives.

A dynamically changing society and its growth into Society 4.0 require attention to innovation-inducing factors in the interest of improving well-being, which is conditioned by proper performance.

The purpose of this article is to pay attention to the state of exploitation of pro-innovation resources in the individual EU countries, but also in their regions in terms of their impact on performance, in the period of the emergence of a new socio-economic paradigm related to the digital economy and the formation of Society 4.0. The aim of the article is to verify the following hypotheses:

$\alpha$ ) There is a significant dependence between the performance of the economy and the intensity of R\&D in the EU.

$\beta$ ) There is a significant positive correlation among the EU countries between:

a. the performance and share of employed university graduates or persons working in the field of science and technology;

b. the performance and share of those employed in the high-tech sector.
At the same time, it is the intention of the authors to classify the regions of the EU countries according to their level of performance and the level of pro-innovative human resources used. The verification of hypotheses will help answer questions that are at the centre of attention in strategic decision-making and in the direction of innovative regional policies; the results may also extend the theoretical knowledge of the economic implications of innovation for national and regional economies.

\section{Theoretical Background}

The EU Member States are still characterised by different innovation performance and different approaches to the management of innovative activities (Stiglitz, 2015), and there is relatively high variability in achieving the Europe 2020 target in relation to research and development support (Tkac, Dulova-Spisakova \& Gontkovicova, 2017). In general, the thesis on the increasing role of so-called intensive factors of development (quality of human resources, application of science and development, technological and non-technological innovation, etc.) is generally accepted in assessing the impact of aggregate productivity on economic growth (Hajek \& Mihola, 2009). However, increasing R\&D spending alone is not enough. Herrera-Echeverri (2017) points out that public spending on research and development is much more effective in countries with "high institutional quality", and the conditions he mentions for the development of partnerships, "scientific production work" and "venture capital" show possible ways of development in this area. Similarly, in terms of innovation performance, the sectoral structure of the economy is important (Kraftova, Mateja \& Zdrazil, 2013) as is its focus on the knowledge- intensive sector. In addition, according to Krafft, Quatraro and Saviotti (2014), its development depends on the life cycle of this sector, the strength of the region in the field, and also on "the general 
features of the economic environment of the region". For many countries and regions, the key to the economic growth and innovation performance of high tech firms is characterised by at least $5 \% \mathrm{R} \& \mathrm{D}$ investment, at least a 10 $\%$ share of university graduates and a product based on advanced, unique or leading technology (Baruch, 1997; Kraftova \& Kraft, 2008). From the point of view of regional performance, the effect of potential cross-border cooperation in terms of the European Union does not escape attention (Zdrazil \& Kozun-Cieslak, 2017) and often does not have a fully institutionalised form, but can be a platform for the development of innovative activities of Euro regions. Innovative activities driven by investment in R\&D should play a crucial role in fulfilling the vision of sustainable growth, and the development of the dynamics of the changes in the use of resources, the orientation of investment and technical development, as well as the development of institutional structures, are brought into line with current and future needs (Galvas \& Kubatova, 2006; Ho \& Lee, 2015). One cannot forget the varying levels of public expenditure commitment to meeting the needs of the country's citizens. M. Halaskova and R. Halaskova (2017) show a variation spread of European countries at 30 percentage points in the indicator of the percentage of government gross domestic product expenditure between liberally oriented countries (30\%) and Scandinavian countries $(60 \%)$. The efficiency usefulness and effectiveness - of the use of pro-innovation resources in individual regions is also differentiated (Kraftova \& Kraft, 2016).

In his introductory speech at the $5^{\text {th }}$ European University Business Forum, A. Vassiliou calls for the implementation of different forms of cooperation and partnership between the academic and business spheres, recalling the Knowledge Alliances pilot project proclaimed in 2011 by the European Parliament and co-financed from the EU budget, at the same time presenting the European paradox: "despite excellence in research, highly skilled graduates and dynamic companies, we are still lagging behind competitors in terms of business creation and bringing ideas to market." (Vassiliou, 2013, 5) Partnership in the form of so-called Triple Hellix (cooperation between universities - industry - governments) combine Rang and Etzkowitz (2013) with two complementary perspectives: neo-institutional and neo-evolutionary, reflecting a new vision of the interactions of the three groups of actors. This is even referred to as a strategic structure in regional development processes (Kinnunen et al., 2016). Such partnerships can become an important driving force for regional development (Mateja, 2009), which stimulates the development of so-called smart specialisation - i.e. economic, scientific and technological specialisation - of regions connected with the stimulation of the entrepreneurial spirit and interplay between institutions, innovations and development (Zitek \& Klimova, 2016a; Kotnik \& Petrin, 2017; Morgan, 2017). This smart specialisation can also play a significant role in terms of the applied types of knowledge bases in the regions - analytical, synthetic, symbolic and their combinations - which then necessarily determine the implementation of regional innovation policy, as pointed out by Zitek and Klimova (2016b). If innovation is perceived as the driving force behind economic growth and regional development and its fundamental parts are knowledge intensive activities, it is necessary for regional policy to support such a configuration of regional environment factors that will contribute to the development of these knowledge- intensive activities (Domenech, Escamilla \& Roin-Ttierno, 2016; GlinskaNewes et al., 2017). European regions are characterised by differences in their performance, resulting, among other things, from their geographical differences, the differences between urban and rural regions, etc. Capello and Lenzi (2016) warn against the inadequacy of internal scientific research and technological activities for socio-economic growth in the regions, and Pagliacci (2017) highlights the need for a "place-based" approach to achieve the Europe 2020 goals, although this requires a great deal of effort.

\section{Methodology}

Performance is measured by the relative GDP value, i.e. GDP per capita, both at the national level (GDP-PC) and at the NUTS 2 (RGDP-PC) level. Under investigation are both the EU Member States (28, including the currently exiting UK) and European regions at the NUTS 2 level, after the year 2011, since there have been 275 (excluding the Extra-Regio).

As the pro-innovation factor, R\&D intensity was selected at the national level and quantified as a percentage of $R \& D$ expenditures in its structure: expenditures of the business enterprises sector (BERD), government sector (GERD), higher education sector (HERD) and private non-profit sector (NGORD).

At the regional level, two pro-innovation factors focusing on the involvement of human resources are included in the analysis, both human resources in science and technology (HRST) according to OECD (OECD, 1995), i.e. the active population in the 15-74 age group having successfully completed education at the tertiary level or being employed in science and technology as a percentage of the total active population aged 15-74, and employment in high-tech sectors as a percentage of total employment (EHTS). The data are aggregated according to the sectoral approach at NACE Rev. 2 on a 2-digit level. The analysis is abstracted from the possible mobility or migration of employees, not only due to the absence of relevant statistical data but also with regard to the fact that these processes are generally perceived as marginal.

In the first part of the survey, Eurostat data were processed for the 11-year period of 2004-2014, i.e. the latest data available on GDP-PC and R\&D in the same time period. At the same time, this period can be divided into three parts in terms of the EU-28 GDP-PC: growth of four years 20042007; the three-year crisis period with the beginning in 2008, with its bottom in the year 2009 and growth in 2010, but still below 2008; the year 2011, when the level of 2008 was exceeded, is the initial period of the last four-year time horizon of 2011-2014. The second part of the research for the NUTS 2 region level, concerning the relationship between RGDP-PC and HRST, or EHTS, focuses on the year 2014, i.e. the year associated with the explicit expression of Germany's quest to become the leader of the Fourth Industrial Revolution and at the same time the first year of the new programming period of the European Union, 
in which the strategy of smart specialisation is perceived as a necessary condition for the drawing European Structural and Investment Funds.

To verify the hypothesis and the relationship between the performance of national economies (GDP-PC as a dependent variable) and their R\&D expenditure (R\&D as an independent variable) a regression function has been sought that would not have a random component of dispersion greater than two-fifths, or the determination coefficient would exceed $60 \%$. (This value is derived from the consideration that in linear relationships the determination coefficient is the second power of the correlation coefficient, according to Table 1 above the level of 0.6 is considered the mean higher significance of the relationship.)

In the second part of the research, the Pearson correlation coefficient was used to determine the correlation rate at the NUTS 2 level between the regional indicators of RGDP-PC and HRST and between RGDP-PC and EHTS - verification of hypothesis $\beta \mathrm{a}$ and $\beta \mathrm{b}$. The results are evaluated according to the following scale - see Table 1, which modifies the frequently-used three-step scale (Taylor, 1990).
Table 1

Scale for Evaluating Correlation Coefficient Results

\begin{tabular}{|c|c|}
\hline Correlation coefficient value & Interpretation of the result \\
\hline $1.00>|r| \geq 0.80$ & High dependency \\
\hline $0.80>|r| \geq 0.60$ & Medium-high dependency \\
\hline $0.50>|r| \geq 0.30$ & Medium dependency \\
\hline $0.30>|r| \geq 0.10$ & Medium-low dependency \\
\hline $0.10>|r| \geq 0.00$ & Low dependency \\
\hline
\end{tabular}

Source: own processing

For the classification of regions, a special classification matrix with quadrants defined by intervals for the relationship between HRTS and RGDP-PC was created and for the EHTS and RGDP-PC relationship taking into account the reality of the EU NUTS 2 regions. These intervals are defined by zero, median and maximum of each indicator considered - see Table 2. In order to emphasise the causal-consequence relationship, RGDP-PC is always considered as the second member of a pair in marking the MIN-MAX and MAX-MIN quadrants.

Table 2

Matrix Intervals of Indicator Values for the Quadrants Considered

\begin{tabular}{|c|c|c|c|c|c|c|}
\hline Quadrant matrix & \multicolumn{3}{|c|}{ MIN-MIN } & \multicolumn{3}{|c|}{ MAX-MAX } \\
\hline Indicator & EHTS & HRST & RGDP-PC & EHTS & HRST & RGDP-PC \\
\hline Interval & $\langle 0 ; 3>)$ & $\langle 0 ; 41.6\rangle$ & $\langle 0 ; 24,300\rangle$ & $\langle 3 ; 11\rangle$ & $\langle 41.6 ; 66.7\rangle$ & $\langle 24,300 ; 73,000\rangle$ \\
\hline Unit & $\%$ & $\%$ & PPS EUR & $\%$ & $\%$ & PPS EUR \\
\hline Quadrant matrix & \multicolumn{3}{|c|}{ MIN-MAX } & \multicolumn{3}{|c|}{ MAX-MIN } \\
\hline Indicator & EHTS & HRST & RGDP-PC & EHTS & HRST & RGDP-PC \\
\hline Interval & $\langle 3 ; 11\rangle$ & $\langle 41.6 ; 66.7\rangle$ & $\langle 0 ; 24,300\rangle$ & $\langle 0 ; 3\rangle$ & $\langle 0 ; 41.6\rangle$ & $\langle 24,300 ; 73,000\rangle$ \\
\hline Unit & $\%$ & $\%$ & PPS EUR & $\%$ & $\%$ & PPS EUR \\
\hline
\end{tabular}

Source: own processing

For regression and correlation analysis, offset and maximum and minimum values were tested using the Dixon test (Dixon, 1951) at a significance level of $\alpha=0.05$. In the case of the countries, the (maximum) offset value was presented for GDP-PC Luxembourg, and therefore it was excluded from the regression analysis; in the case of NUTS 2 regions, one offset value (maximum) for RGDP-PC was also found for NUTS 2 Inner London West, which was subsequently excluded; (noteworthy was that this region was once again in first place in terms of HRST, albeit not as an offset value, but in the EHTS it was only in $12^{\text {th }}$ place).
Another problem was the absence of 22 pieces of data (for NUTS 2 regions of eight EU countries not containing the capitals) of 275 for the EHTS indicator in 2014. As a method of estimating these data, adding the closest value over time (for 7 regions) and a less precise method for regions where EHTS values were completely absent (15 regions) by adding the average NUTS 2 data for the country concerned, without including the regions containing the capital cities, as these regions usually have significantly higher values.

For the sake of clarity, the country's international abbreviations are used.

Table 3

Overview of the EU Member State Abbreviations

\begin{tabular}{|l|l|l|l|l|l|l|l|}
\hline BE & Belgium & EL & Greece & LT & Lithuania & PT \\
\hline BG & Bulgaria & ES & Spain & LU & Luxembourg & RO & Romania \\
\hline CZ & Czech Republic & FR & France & HU & Hungary & SI & Slovenia \\
\hline DK & Denmark & HR & Croatia & MT & Malta & SK & Slovakia \\
\hline DE & Germany & IT & Italy & NL & Netherlands & FI & Finland \\
\hline EE & Estonia & CY & Cyprus & AT & Austria & SE & Sweden \\
\hline IE & Ireland & LV & Latvia & PL & Poland & UK \\
\hline
\end{tabular}

Source: own processing with the use of the Eurostat Yearbook (2004)

\section{Research Results}

Performance and Intensity of Research and Development at the National Level
The performance of the EU-28 measured by GDP-CP monitored in the eleven-year period has been steadily growing slightly (growth rate of 2014/2004 was 1.23), with the exception of a drop between 2008 and 2009 (0.94) in response to the global economic crisis, where the level of 2008 was exceeded only in 2011. The EU's three largest 
economies (DE, UK, FR), the BENELUX countries (with Luxembourg being the maximum offset), three Scandinavian countries (DK, SE, FI) and also Austria and Ireland are above the EU-28 throughout the period under review for per capita wealth. Italy has also held the EU-28 GDP-PC up to 2012, but has fallen below low-performing countries, including three Southern European economies (PT, ES, EL) and all countries that joined the EU in 2004 or later.

R\&D intensity measured by R\&D has not increased significantly in the EU-28 over the eleven-year period of 2004-2014, with a growth index of less than 1.15 compared to GDP-PC growth. In the long run, seven countries out of the top ten (FI, SE, DK, AT, DE, BE, FR - ranked in descending order) are above the EU-28 R\&D level; in addition, Slovenia also joined in 2010, and Estonia joined in 2011 and 2012. The highest R\&D values in 2009 were reached by Finland, namely $3.75 \%$ of its GDP, and together with Sweden over the long-term they exceeded the desired $3 \%$ level of this indicator.

In connection with the abovementioned loss of Europe's position in the world economy, a comparison of the R\&D indicator of the individual EU Member States with the selected economies of the world was performed, i.e. its average values for 2004-2014. The result of this comparison.

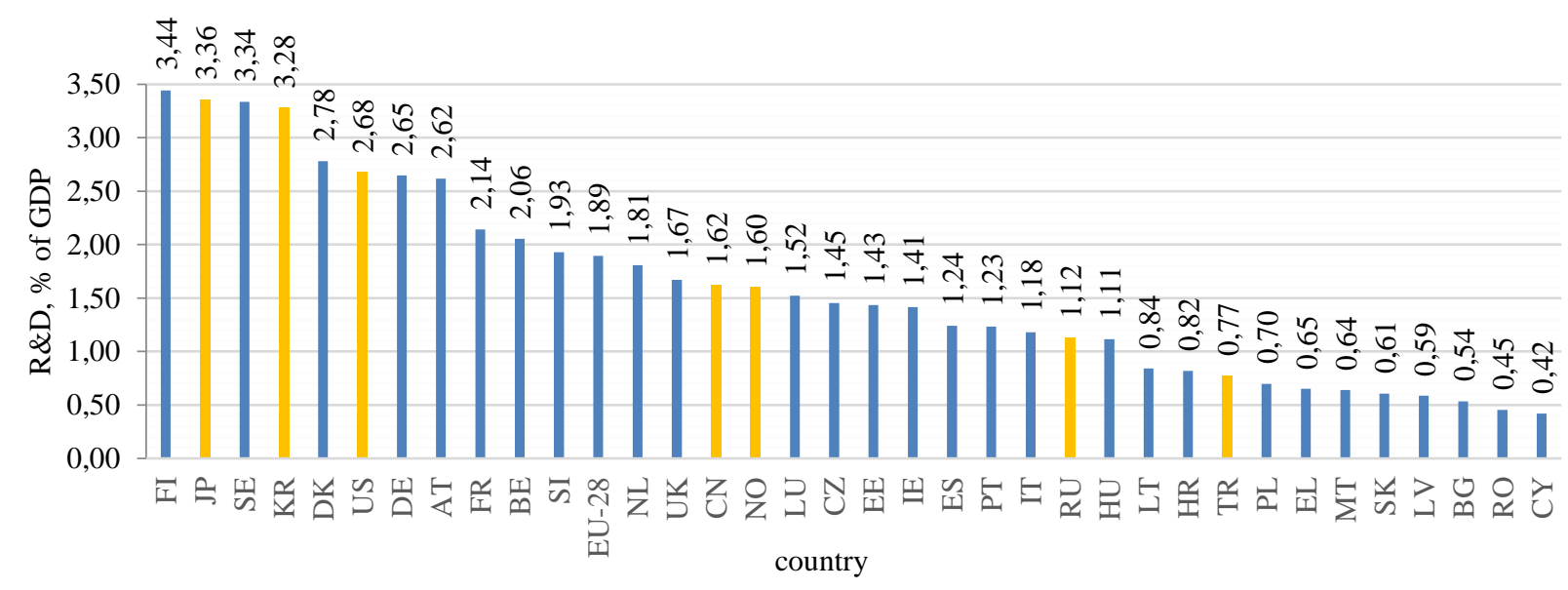

Figure 2. Comparison of the Average R\&D of Selected Countries for 2004-2014

Note 1: For abbreviations of countries, see Table 3, CN=China (without Hong Kong), JP=Japan, KR=South Korea, NO=Norway, RU= Russia, TR=Turkey, US=United States.

Note 2: The US average is related to 2003-2012; averages for CN, JP and KR are relative to 2003-2013.

Source: own processing with the use of Eurostat data (2016e)

The three northern EU Member States are spending more of their GDP than the USA on research and development. Finland and Sweden are among the four "world leaders" over $3 \%$, together with Japan and South Korea.

Germany and Austria are also keeping pace with the USA. In addition to these two, EU-28 average R\&D (i.e. only $1.89 \%$ ) is exceeded by Belgium and Slovenia. Most EU Member States have an average spending of $2.14 \%$ to $1.0 \%$ on research and development (FR, NL, UK, LU, CZ, EE, IE, ES, PT, IT, HU). This interval is also reached by China, Norway and Russia. Unfortunately, ten EU Member States range with their average R\&D below $1.0 \%$ of GDP (LT, HR, PL, EL, MT, SK, LV, BG, RO, CY) together with Turkey; see Figure 2. Romania and Cyprus do not reach even half the percentage of expenditure monitored on its GDP.

When verifying hypothesis $\alpha$, the relationship between the performance of the national economy (GDP PC) and R\&D intensity (R\&D), the most suitable was found to be the second order polynomial function, whose quadratic equation

$$
y=-2,022.6 x^{2}+17,933 x+1,292
$$

shows a coefficient of determination $\mathrm{R}^{2}=0.6355$, which meets the required level of research. Therefore, hypothesis $\alpha$ was accepted. However, not only the relationship between the average values of the indicators of the EU Member States for the period 2004-2014 but also in individual years was tested. The linear regression function (increasing) presenting the direct proportion was related to the determinant coefficient above the level 0.6 at 3 years of the monitored eleven $(2010,2013,2014)$, the logarithmic function reached the required level of the determination coefficient only in 2004. The relationship between R\&D and GDP-PC is best described by a quadratic equation, the determinant of which exceeded the required level of research in all the monitored years with the exception of 2011 and 2012.

Regression functions in the form of a parabola for the 2004-2014 average - see Figure 3 - show that the contribution of $\mathrm{R} \& \mathrm{D}$ expenditures to economic performance is not constant and that there is probably a certain degree of saturation where the increase in these expenditures is associated with a lower increase of performance. In addition, other factors may affect the economy, for example, the Czech Republic and Ireland spend roughly the same amount on R\&D, but the GDP-PC economy is diametrically different; Cyprus is comparable to Romania in the area of R\&D spending, but its GDP-PC is, however, much higher. 


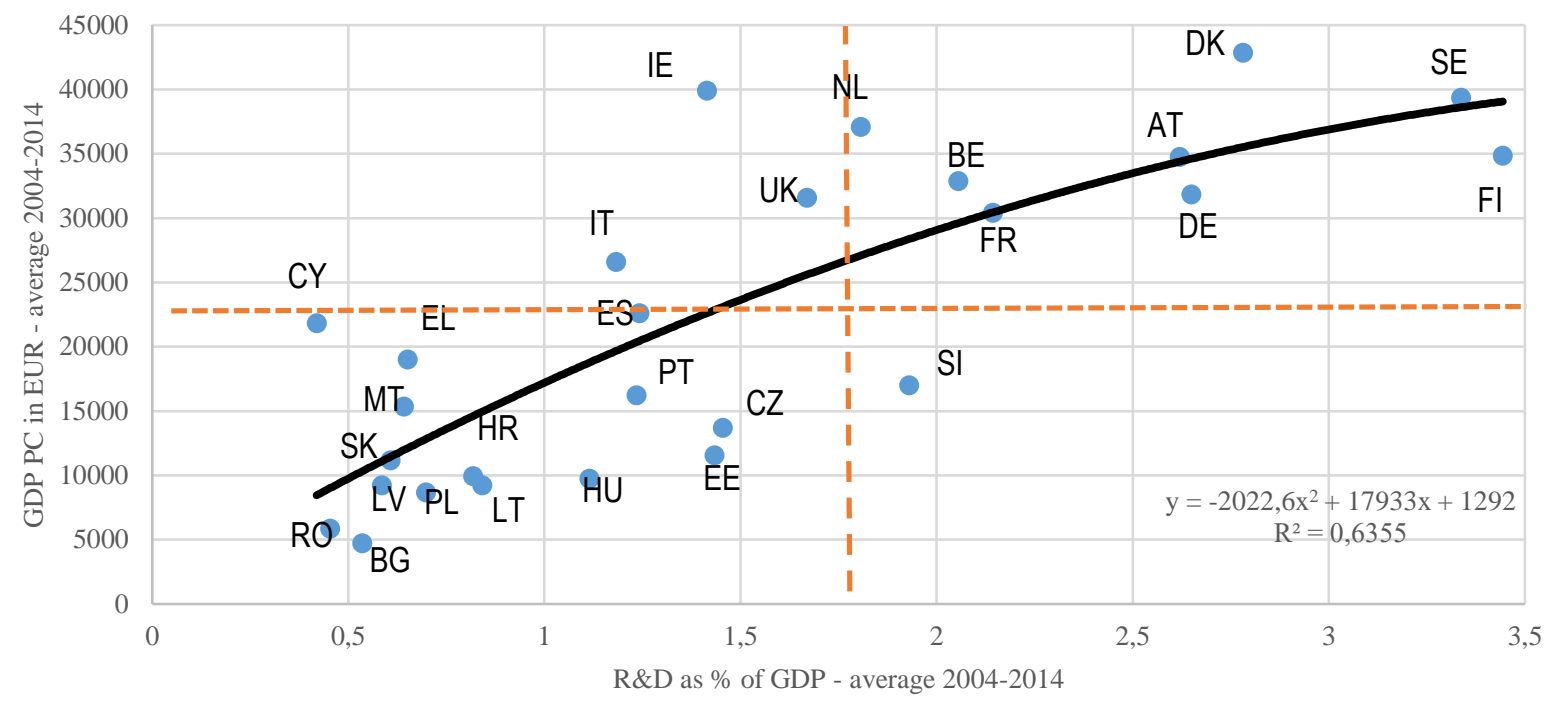

Figure 3. Regression Features Capturing GDP-PC Dependence on the EU-28 R\&D

Source: own processing with the use Eurostat data (2016b; 2016e)

Needless to say, the effectiveness of the use of allocated resources for research and development plays a role. The case of Finland and Sweden shows that while Finland spends slightly more on R\&D than Sweden, Sweden achieves higher performance with its spending. The parabola in Figure 3 defined by equation (1) essentially divides the points in the Figure 3 (the EU countries) into two groups:

- those countries that are above it have higher performance (GDP-PC) depending on their R\&D spending;

- on the contrary, those who occupy a position under the parabola do not have adequate reflection of their spending on R\&D in the creation of their wealth.

In this context, Slovenia is an interesting case, which has more relative R\&D expenditures than the Netherlands and the United Kingdom but does not reach their economic performance, although it is exceeded only by the "peculiar" Cyprus, which joined the EU after 2003, with the lowest value $R \& D$ at the average GDP-PC level.

\section{The Importance of the R\&D Expenditure Structure}

The internal structure of $R \& D$ expenditures in the individual EU Member States was also examined. It turns out that the four classified R\&D elements (i.e. BERD business enterprises sector, GERD - government sector, HERD - higher education sector and NGORD - private non-profit sector) are used differently by country and their impact on economic performance.

The maximum share of BERD is achieved by Finland (2.15\% of GDP), Sweden (2.12\% of GDP) and Austria $(2.11 \%$ of GDP). There are four other countries (DK, DE, FR and BE) above the $1.5 \%$ BERD of GDP, i.e. the countries that appear in Figure 3 in the upper right quadrant, plus exceptional Slovenia. At the same time, eight of them exceeded the level of two-thirds of the BERD in R\&D in 2014; in descending order, these are SI, IE, BE, HU, AT, DE, FI and SE.
In general, the second most significant element of these expenditures is HERD. Its maximum share in total R\&D is reached by Denmark (1.01\% of GDP); over $0.5 \%$ of GDP is spent in this segment by eight EU countries (SE, AT, FI, $\mathrm{EE}, \mathrm{NL}, \mathrm{PT}, \mathrm{LT}, \mathrm{CZ}$ ), representing a mix of the top right (SE, AT, FI, NL) and left lower quadrant (PT, CZ, EE, LT). In the upper right quadrant, we could probably speak of the saturation limitation, but in the left lower quadrant there are likely to be financing opportunities.

Government spending on research and development (GERD) is maximised by Germany (but it is only $0.42 \%$ of GDP), followed by the Czech Republic and Luxembourg $(0.36 \%)$, followed at a certain distance by France $(0.3 \%)$.

Outsiders in funding research and development are of non-governmental non-profit organisations. The maximum of this segment is shown by minimalist Cyprus (from R\&D point of view), at $0.08 \%$ of its GDP.

In terms of structure, it would be possible to classify the four elements in terms of the impact on economic performance as follows: 1. BERD, 2. HERD, 3. GERD and 4. NGORD. It can be deduced that the most significant influence on growth in wealth creation is the support of research and development by entrepreneurial subjects, followed by the allocation of resources to higher education. At a certain distance, government spending on research and development generate growth impulses, and spending by non-governmental non-profit organisations is relatively non-significant.

\section{Relationship of Pro-Innovation Factors and Performance in the EU Regions at the NUTS 2 Level}

When examining the correlation between the performance of the EU regions at the NUTS 2 level measured by RGDP-PC in the reference year 2014 and the proportion of employed persons with higher education and persons in the field of science and technology (HRST) - 
verification of the $\beta$ a hypothesis - a positive mean higher correlation $(r=0.72)$ was found; see Table 1 .

In addition, the correlation between equally quantified regional performance and the share of persons employed in high-tech sectors (EHTS) - verification of the $\beta b$ hypothesis - which also achieves a positive medium-high level, is, however, lower than the correlation coefficient between RGDP-PC and HRST by roughly 11 percentage points, $r=$ 0.61 .

\section{Classification of NUTS 2 regions by HRST and RGDP-PC levels}

If we apply a matrix view of the NUTS 2 regions of the EU in the sense of the defined values and quadrants in Table 2 , we reach the relatively interesting results quantified in Table 4.

Table 4

NUTS 2 Numbers according to the relationship between their HRST and RGDP-PC

\begin{tabular}{|l|c|c|}
\hline $\begin{array}{l}\text { Designation of a matrix } \\
\text { quadrant }\end{array}$ & MIN-MIN & MAX-MAX \\
\hline $\begin{array}{l}\text { Number of classified } \\
\text { NUTS 2 }\end{array}$ & $93(34 \%)$ & $117(43 \%)$ \\
\hline $\begin{array}{l}\text { Designation of a matrix } \\
\text { quadrant }\end{array}$ & MIN-MAX & MAX-MIN \\
\hline $\begin{array}{l}\text { Number of classified } \\
\text { NUTS 2 }\end{array}$ & $40(14 \%)$ & $24(9 \%)$ \\
\hline
\end{tabular}

Source: own processing with the Eurostat data (2016c, 2016d)

This simple classification again proves the link between the performance of the economy and the share of human resources in science and technology, whether in the form of acquired tertiary education or in the form of active participation in science and technology. The MAX-MAX quadrant represents the largest proportion of regions (43\%) in which the higher than average HRTS value is greater than the average RGDP-PC. At the same time, the second largest part of the regions (34\%) does not reach higher than a median RGDP-PC value at the current median HRTS limit indicator. A small group of regions (14\%) is able to extract relatively high RGDP-PC from low HRST, or other major factors influencing the economic performance of the region can be considered. This is a relatively diverse range of regions of the traditional EU Member States, including Malta and two regions of the former GDR. On the contrary, in a group of regions (9\%) with a relatively high share of HRST showing relatively low economic performance, onefourth of so-called new Member States are represented. These regions, therefore, are not yet sufficiently using the potential of their human resources in science and technology.

If the threshold of the median RGDP-PC value of $€ 24,300$ shifts, for example, to the required high economic output of $€ 40,000$, then only 17 NUTS 2 regions of the EU (i.e. slightly over $6 \%$ ) would join this group from the MAXMAX quadrant. They can be said to be able to use their HRST to encourage the high creation of wealth in the region. It is also interesting that these regions belong to individual national economies: CZ (Prague); DK (Hovedstaden); DE (Stuttgart, Oberbayern, Bremen, Hamburg, Darmstadt); FR (Île de France); LU
(Luxembourg); NL (Groningen, Utrecht, North-Holland); AT (Vienna, Salzburg); SK (Bratislava Region); SE (Stockholm) and UK (Inner London - East), but also that all the metropolitan regions of these countries belong to this group, with the exception of Germany.

\section{Classification of NUTS 2 regions by EHTS and RGDP-PC levels}

When assessing the NUTS 2 regions of the EU in terms of the relationship between their allocation of human resources in the high-tech sector and economic performance, it is not - compared to the previous findings a very different situation, see Table 5 .

Table 5

NUTS 2 Numbers according to the Relationship between their EHTS and RGDP-PC

\begin{tabular}{|l|c|c|}
\hline $\begin{array}{l}\text { Designation of a matrix } \\
\text { quadrant }\end{array}$ & MIN-MIN & MAX-MAX \\
\hline $\begin{array}{l}\text { Number of classified } \\
\text { NUTS 2 }\end{array}$ & $87(32 \%)$ & $107(39 \%)$ \\
\hline $\begin{array}{l}\text { Designation of a matrix } \\
\text { quadrant }\end{array}$ & MIN-MAX & MAX-MIN \\
\hline $\begin{array}{l}\text { Number of classified } \\
\text { NUTS 2 }\end{array}$ & $50(18 \%)$ & $30(11 \%)$ \\
\hline
\end{tabular}

Source: own processing with the use of Eurostat data (2016a, 2016d)

A total of $71 \%$ of the EU regions (the sum of the MINMIN and MAX-MAX quadrants) show an interdependence between the EHTS level and the economic performance of the region measured by the RGDP-PC.

The MIN-MIN quadrant roughly corresponds to the relationship between RGDP-PC and the regional HRTS. The intersection of both MIN-MIN quadrants occurs at 74 NUTS 2, i.e. in $27 \%$ of European regions the low RDGPPC is associated with both low HRTS and low EHTS.

The EU regions with a high level of EHTS associated with high performance are 4 percentage points lower in the MAX-MAX quadrant of Table 5 than in the fourth quadrant of Table 4. "Stars", which make their significant investment in employment in the high-tech sector their economic output, are the twelve following NUTS 2 (selection from the MAX-MAX quadrant): BE (Reg. Bruxelles/Brussels Gewest); CZ (Prague); DK (Hovedstaden); DE (Oberbayern, Darmstadt); IE (Southern and Eastern); FR (Île de France); AT (Vienna); SK (Bratislava Region); SE (Stockholm); UK (Inner London-East; Berkshire, Buckinghamshire and Oxfordshire). These regions (once again the metropolitan regions prevail) can allocate a high proportion of employees to the high-tech sector, but mainly their allocation is linked to the high economic performance of the region. It can be inferred that the share of universityeducated and R\&D personnel and the transformation of science and technology into the real economy materialised in the high-tech sector is significant for the performance of the economy. This is confirmed by the comparison of both MAX-MAX quadrants, where their intersection represents $32 \%$ of the 274 European NUTS 2 regions.

The regions that in terms of wealth creation inefficiently use both HRTS and EHTS (intersection of both MAX-MIN quadrants) represent a group of (again) twelve NUTS 2 that belong both to the traditional (9) and the new (3) EU 
Member States. In particular, these are NUTS 2: UK (Tees Valley and Durham, Merseyside, Northern Ireland, Shropshire and Staffordshire, Northumberland and Tyne and Wear), BE (Prov. Luxembourg, Prov. Namur), FR (Franche-Comté), DK (Sjælland), BG (Yugozapaden), PL (Dolnoslaskie) and Estonia.

On the contrary, there are 29 regions that are able to achieve high economic performance with a relatively low level of HRST and EHTS (intersection of both MIN-MAX quadrants), i.e. over $10 \%$. Among these regions which effectively boost the value of their small human resources in the high-tech sector are the regions of DE (Stuttgart, Bremen, Hamburg), Luxembourg, the regions of $\mathrm{NL}$ (Groningen, Utrecht, North-Holland) and the UK (North Eastern Scotland). In other words, there are other factors in these regions driving the economy.

\section{Conclusion}

The EU's demand for R\&D intensity quantified as R\&D>3 \% was certainly ambitious in 2000. This requirement persists. Average values for the 2004-2014 period exceeded the stated figure for only four countries, in two EU countries (FI, SE), Japan and South Korea. The situation of the Member States is alarming in terms of implementing their innovation policy, where the average value of this indicator is below $0.5 \%$ (RO, CY). However, the situation of countries with a value of between $0.5 \%$ and 1\% (seven Member States joining the EU after 2003 and Greece) would require a re-evaluation of their innovation strategy.

Regression functions capturing the relationship between $\mathrm{R} \& \mathrm{D}$ intensity and parabolic performance of the economy point to the fact that the contribution of $R \& D$ spending to economic performance is not unchanged. There is a very likely degree of saturation for which the increase in these expenditures is associated with lower performance gains, although it is impossible to ignore the possible nonnegligible impact of specific conditions in each country. R\&D structure certainly plays a role. From research results, it can be deduced that the most important influence on the growth of wealth creation is the support of research and development by entrepreneurial subjects, followed by the degree of allocation of funds to higher education. Only with a certain distance - given their scale - do governmental expenditures in R\&D deliver growth impulses. Relatively insignificant are expenditures in this sector from nongovernmental non-profit organisations.

Although the degree of the correlation between the economic performance of the regions and the two assessed pro-innovation sources (HRST and EHTS) is in the median higher correlation score, it is not negligible, with a certain distance (11 percentage points) of the correlation coefficient between RGDP-PC and the share of people employed in the high-tech sector, compared to the HRST correlation. This can emphasise both the role of research itself and the importance of university-educated workers, especially with an emphasis on the development of a knowledge-based economy.

The link between HRST and wealth creation is illustrated by $77 \%$ of the EU regions, either by the low share of university-educated workers and science and technology workers being associated with low RGDP-PC or on the contrary, by high RGDP-PC generation. At the same time, it cannot be overlooked that the MAX-MAX relationship between HRTS and RGD-PC contains the highest values in regions that represent or include the capital of the country. Similarly, the link between EHTS and the economic performance of the region measured by RGDP-PC shows the reality of $71 \%$ of the EU regions. The low RGDP-PC is connected in less than one-third of European NUTS 2 with low levels of both HRTS and EHTS, while in one-third of regions the high RGDP-PC is determined by the high level of HRTS and EHTS. From this it can be concluded that for the performance of the economy both the share of university-educated and those involved in $\mathrm{R} \& \mathrm{D}$ and the transformation of the results of science and technology into the real economy materialised in the high-tech sector are important.

The results of the analysis and confirmation of established hypotheses can be used in the development and updating of the EU innovation policies, where $R \& D$ remains a significant impulse, their level and structure, as the BERD and HERD are the most significant, they should be preferred in the countries with lower performance. The demonstrated correlation between selected human resources groups (HRST and EHTS) together with the classification of NUTS 2 regions of the EU countries can in turn guide the development and updating of strategic development plans of individual regions, especially in the context of the transition to the digital economy and the formation of the Society 4.0.

And precisely because innovation, research and development, based on intuition and invention, are human domains (because the creator of artificial intelligence is also human), it is important not to forget while assessing the relationship between pro-innovation factors with economic performance such a seemingly inner entity like interpersonal relationships. Based on this, non-formal and formal knowledge alliances can be created, which should be supported both by regional and national innovation policies. Whether this "soft element" from the area of pro-innovation factors, representing the interconnection of human and social capital, can result in a regionally significant smart specialisation that produces positive economic growth effects seems to be a possible direction for follow-up research.

\section{Acknowledgements}

This work was supported by the University of Pardubice and Technical University in Liberec in the framework of solving the project "Regional Development of the Czech Republic in the Context of the Onset of the $4^{\text {th }}$ Industrial Revolution." 


\section{References}

Baruch, Y. (1997). High technology organization - what it is, what it isn't. International Journal of Technology Management, 13(2), 179-195. https://doi.org/10.1504/IJTM.1997.001650

Capello, R., \& Lenzi, C. (2016). Relevance and utility of European Union research, technological development and innovation policies for a smart growth. Environment and Planning C-Government and Policy, 34(1), 52-72. https://doi.org/10.1177/0263774X15614655

Dixon, W. J. (1951). Ratios Involving Extreme Values. The Annals of Mathematical Statistics, 22 (1), p. 68-78. https://doi.org/10.1214/aoms/1177729693

Domenech, J., Escamilla, R., \& Roig-Tiern, N. (2016). Explaining knowledge-intensive activities from a regional perspective. Journal of Business Research, 69(4), 1301-1306. http://doi.org/10.1016/j.jbusres.2015.10.096

European Commission. (2010). Europe 2020. A strategy for smart, sustainable and inclusive growth. COM (2010) 2020 final.

European Communities. (2004). Facing the Challenge. The Lisbon strategy for growth and employment. Report from the High Level Group chaired by Wim Kok. Available from internet: http://dspace.ceu.es/bitstream/10637/2481/1/ Kok_W.pdf

Eurostat. (2004). Eurostat Yearbook. Available from internet: http://ec.europa.eu/eurostat/documents/3217494/5648861/KS-CD04-001-EN.PDF/05371ffe-c41c-4bec-9093-f507c11cf3ca

Eurostat. (2016a). Employment in high-tech sectors by NUTS 2 regions. Available from internet: http://ec.europa.eu/eurostat/tgm/table.do?tab=table\&init=1\&plugin=1\&language=en\&pcode=tgs00039

Eurostat. (2016b). Gross domestic product at market prices. (Current prices, euro per capita). Available from internet: $\mathrm{http}: / /$ ec.europa.eu/eurostat/tgm/table.do?tab=table\&init=1\&plugin=1\&language=en\&pcode=tec 00001

Eurostat. (2016c). Human resources in science and technology (HRST) by NUTS 2 regions. Available from internet: $\mathrm{http}: / /$ ec.europa.eu/eurostat/tgm/table.do?tab=table\&init=1\&plugin=1\&language $=$ en\&pcode $=\operatorname{tgs} 00038$

Eurostat. (2016d). Regional gross domestic product (PPS per inhabitant) by NUTS 2 regions. Available from internet: $\mathrm{http}: / /$ ec.europa.eu/eurostat/tgm/table.do?tab=table\&init=1\&plugin=1\&language $=$ en\&pcode $=\operatorname{tgs} 00005$

Eurostat. (2016e). Research and development expenditure, by sectors of performance. Available from internet: http://ec.europa.eu/eurostat/tgm/table.do?tab=table\&init=1\&plugin=1\&language=en\&pcode=tsc00001

Galvas, M., \& Kubatova, J. (2006). Vybrane aspekty vztahu prava a trvale udrzitelneho rozvoje. [Selected aspects of law and sustainable development.] Politologica 5, 1st edition, 9-24. Available from internet: http://www.upol.cz/ fileadmin/user_upload/Veda/AUPO/AUPO_Politologica_V.pdf

Glinska-Newes, A., Sudolska, A., Karwacki, A., \& Gorka, J. (2017). Innovations among People. How Positive Relationships at Work Can Trigger Innovation Creation. E+M Ekonomie a management, 20(3), 84-100. https://doi.org/10.152 40/tul/001/2017-3-006

Hajek, M., \& Mihola, J. (2009). Analyza vlivu souhrnne produktivity faktorů na ekonomicky růst CR. [Analysis of total factor productivity contribution to economic growth in the Czech Republic.] Politicka ekonomie, 57(6), 740-753. https://doi.org/10.18267/j.polek.708

Halaskova, M., \& Halaskova, R. (2017). Public Expenditures in Areas of Public sector: Analysis and Evaluation in EU Counries. Scientific Paper of the University of Pardubice. Series D. 24 (39-1/2017), 39-50. http://hdl.handle.net/ $10195 / 66926$

Herrera-Echeverri, H. (2017). Public Expenditure in Research and Development and Venture Capital Commitments. Inzinerine Ekonomika - Engineering Economics, 28(3), 240-252. http://dx.doi.org/10.5755/101.ee.28.3.13216

Ho, J. C., \& Lee, Ch.-S. (2015). A typology of technological change: Technological paradigm theory with validation and generalization from case studies. Technological Forecasting \& Social Change, 97, 128-139. http://dx.doi.org/10. 1016/j.techfore.2014.05.015

Kinnunen, T., Rinkinen, S., Majava, J. et al. (2016). Strategic Structure and Implementation of Regional Triple Helix Collaboration: Comparative Case Study. 11th European Conference on Innovation and Entrepreneurship (ECIE), 381388.

Kotnik. P. (2017). Implementing a smart specialisation strategy: an evidence-based approach. International Review of Administrative Sciences, 83(1), 85-105. https://doi.org/10.1177/0020852315574994

Krafft, J., Quatraro, F., \& Saviotti, P. P. (2014). Knowledge characteristics and the dynamics of technological alliances in pharmaceuticals: empirical evidence from Europe, US and Japan. Journal of Evolutionary Economics, 24(3), 587-622. https://hal.archives-ouvertes.fr/hal-01070561 https://doi.org/10.1007/s00191-014-0338-8

Kraftova, I., \& Kraft, J. (2008). High tech firmy a tvorba bohatstvi v zemich EMEA. [High tech companies and wealth creation in EMEA countries.] E+M Ekonomie a management, 11(4), 4-20. 
Kraftova, I., \& Kraft, J. (2016). Regionalni rozlozeni proinovacnich zdrojů v Ceské republice a jejich vazba na výkonnost. [The regional distribution of pro-innovation resources in the Czech Republic and their link to performance.] In Klimova, V., Zitek, V. (eds.) 19th International Colloquium on Regional Sciences. Conference Proceedings, $273-281$. https://doi.org/10.5817/CZ.MUNI.P210-8273-2016-34

Kraftova I., Mateja, Z., \& Zdrazil, P. (2013). Innovation Industry Drivers. In Proceedings of the 11th International Conference Liberec Economic Forum, 334-342.

MacDougall, W. (2014). Industrie 4.0. Smart Manufacturing for the Future. Berlin: GTAI.

Mateja, Z. (2009). Meeting of the Mission of Universities in Regions: Forms and Impact. In Proceedings of the 3rd Central European Conference in Regional Science (CERS), 1191-1198.

Morgan, K. (2017). Nuturing novelty: Regional innovation policy in the age of smart specialisation. Environment and Planning C-Politics and Space, 35(4), p. 569-583. http://dx.doi.org/10.1177/0263774X16645106

OECD. (1995). The Measurement of Scientific and Technological Activities Manual on the Measurement of Human Resources devoted to S\&T "Canberra Manual". Available from internet: http://www.conicyt.cl/wp-content/uploads/ 2014/07/Manual-de-Canberra.pdf

Pagliacci, F. (2017). Regional paths towards Europe 2020 targets: a spatial approach. European Planning Studies, 25(4), 601-619. http://dx.doi.org/10.1080/09654313.2017.1280002

PricewaterhouseCoopers. (2017). The long view: how will the global economic order change by 2050? Available from internet: https://www.pwc.com/gx/en/issues/economy/the-world-in-2050.html

Ranga, M., \& Etzkowitz H. (2013). Triple Helix systems: An analytical framework for innovation policy and practice in the knowledge society. Industry and Higher Education, 27(4), 237-262. https://doi.org/10.5367/ihe.2013.0165

Stiglitz, J. E. (2015). Leaders and followers: Perspectives on the Nordic model and the economics of innovation. Journal of Public Economics, 127, 3-16. http://dx.doi.org/10.1016/j.jpubeco.2014.09.005

Taylor, R. (1990) Interpretation of the Correlation Coefficient: A Basic Review. Journal of Diagnostic Medical Sonography, 6(1), 35-39. https://doi.org/10.1177/875647939000600106

Tkac, M., Dulova Spisakova, E., \& Gotkovicova, B. (2017). Research and Development in Slovakia, Denmark and Finland form the Perspective of the Strategy Europe 2020. Scientific Paper of the University of Pardubice. Series D. 24(391/2017), 223-235. http://hdl.handle.net/10195/66943

UNSTAT. (2017). GDP and its breakdown at current prices in US Dollars. Available from internet: https://unstats.un.org /unsd/snaama/dnllist.asp

Valenta, F. (2001). Inovace v manazerske praxi. [Innovation in managerial practice.] Praha: Velryba.

Vassiliou, A. (2013). Opening speech. The 5th European University-Business Forum, Brussels. Available from internet: http://europa.eu/rapid/press-release_SPEECH-13-512_en.htm

Zdrazil, P. \& Kozun-Cieslak, G. (2017). The Role of Cross-Border Cooperation Initiatives in Respect of Regional Development: Case Study of Euroregion Neisse. Scientific Paper of the University of Pardubice. Series D. 24(402/2017), 244-254. http://hdl.handle.net/10195/67942

Zitek, V., \& Klimova, V. (2016a). Aplikace konceptu regionalnich inovacnich systemu a implikace pro inovacni politiku. [Application of the concept of regional innovation systems and implications for innovation policy.] Brno: Masarykova univerzita.

Zitek, V., \& Klimova, V. (2016b). Identification of Knowledge Bases: The Case of the Czech Republic. Inzinerine Ekonomika -Engineering Economics, 27(5), 568-577. http://dx.doi.org/10.5755/j01.ee.27.5.14276

The article has been reviewed.

Received in December, 2017; accepted in October, 2018. 